\title{
Soil respiration, root traits and dry matter yield of sorghum (Sorghum bicolor L.) as affected by biochar application under different cropping patterns and irrigation method
}

\author{
Sara Darvishi Aghajani ${ }^{1}{ }^{(\mathbb{D}}$, Mojtaba Alavifazel $^{2} \mathbb{1}^{*}$, Ghorban Nurmohammadi ${ }^{1}{ }^{(\mathbb{D}}$, \\ Mohammad Reza Ardakani ${ }^{3}$, and Mansur Sarajughi ${ }^{3}$ \\ ${ }^{1}$ Department of Horticultural Science and Agronomy, Science and Research Branch, Islamic Azad University, Tehran, Iran, \\ P.O. Box: 14778-93855 \\ ${ }^{2}$ Department of Agronomy, Ahvaz Branch, Islamic Azad University, Ahvaz, Iran, P.O. Box: 61349-37333 \\ ${ }^{3}$ Department of Agronomy, Karaj Branch, Islamic Azad University, Karaj, Iran, P.O. Box: 31499-68111
}

Received August 28, 2020; accepted November 23, 2020

\begin{abstract}
This study aimed to investigate the effect of alternate furrow irrigation accompanied by biochar application within different cropping patterns on soil respiration and root traits such as root dry weight and root volume associated with the dry matter yield of sorghum (Sorghum bicolor L.) over a twoyear period $(2017-2018)$. The treatments consisted of three irrigation methods, which included every furrow irrigation, fixed furrow irrigation and alternate furrow irrigation and two cropping patterns including one-row, two-rows and three levels of biochar application including 0,6 and $12 \mathrm{t} \mathrm{ha}^{-1}$. Different irrigation levels had a significant effect on root morphological indices, soil respiration, and the dry matter of forage yield. Biochar application showed a significant influence on soil respiration, as the highest soil respiration was observed in the $\mathrm{B} 2$ and $\mathrm{B} 1$ treatments $(0.173$ and $0.171 \mu \mathrm{mol} \mathrm{C} \mathrm{g}^{-1}$ soil h$^{-1}$, respectively), in contrast, the least was observed in the control treatment B0 $\left(0.168 \mu \mathrm{mol} \mathrm{C} \mathrm{\textrm {g } ^ { - 1 }}\right.$ soil $\left.\mathrm{h}^{-1}\right)$. Biochar application had a positive effect on root dry weight, root volume and dry matter yield due to the prevention of severe moisture loss and further yield loss.

Keyw ords: biochar, root dry weight, root volume, soil respiration, Sorghum bicolor L.
\end{abstract}

\section{INTRODUCTION}

Drought and water scarcity are two important factors affecting crop production and soil microbial activity (soil respiration). Therefore, the use of drought-resistant crops and appropriate strategies to improve water storage in the soil would appear to be essential. In many areas of the world irrigation, water is overused (Chai et al., 2014),

*Corresponding author e-mail: alavifazelm@gmail.com while water scarcity is one of the most critical problems in arid and semi-arid regions (Afshari et al., 2020; Forouzani and Karami 2011; Moslemi et al., 2011; Samarbakhsh et al., 2009). However, in a climate change scenario or with the onset of drought, crops may be influenced by drought stress, and agricultural production is expected to plunge. Low-irrigation is a method for optimizing water application which improves the water utilization of plant roots in the soil. Alternate furrow irrigation is one of the ways to save water through improving water use efficiency with the least impact on reducing the production of crops and horticultural plants (Kang and Zhang; 2004; Xiao et al., 2015). Randhawa et al. (2017) examined maize biomass accumulation under water stress conditions and stated that drought stress reduced the dry matter accumulation of maize. Wu et al. (2015) reported that the root water uptake in maize was higher under alternate furrow irrigation conditions than regular irrigation. The hydraulic conductivity of roots indicate their water absorption capacity, which is mainly dependent on the structure, water permeability, and root surface area (Ardakani et al., 2009; Hoseinzade et al., 2016; Sutka et al., 2011; Liu et al., 2014). Plants with deep and extensive roots could also produce a higher yield under drought stress conditions (Chimungu et al., 2014; Liu et al., 2011).

(C) 2020 Institute of Agrophysics, Polish Academy of Sciences 
Sorghum is highly resistant to drought (Borrell et al., 2014). The use of the appropriate cropping patterns could play an important role in maintaining soil moisture in arid and semi-arid regions. The results of the research conducted by Cox et al. (2006) showed the highest dry matter yield of maize in a two-row cropping pattern. The two-row cropping pattern has also been assessed in peanut crops, and it has been observed that this planting method raises the growth rate of this crop and indirectly increases the dry weight of the aerial plant parts (Kurt et al., 2017). Soil texture is one of the most important soil properties that affect the degree of water and nutrient retention, permeability, drainage, ventilation, organic carbon content, buffering capacity, porosity and many mechanical properties of the soil (Akpa et al., 2014).

Biochar application in the soil increases nutrient availability and water storage in the soil (Jeffery et al., 2015). The results of the study performed by Brennan et al. (2014) showed that biochar application in the soil enhanced favourable root traits such as root density and length. Biochar application increased plant height, stem diameter, chlorophyll content, net photosynthesis and grain yield (Sun et al., 2017; Masto et al., 2013). Soil respiration directly correlates with temperature and negatively correlates with moisture, while biochar application and carbon sequestration decreases soil respiration severity (He et al., 2016). In this study, root morphological traits, soil respiration (SR) and the relationships between these parameters and biochar application were investigated.

\section{MATERIALS AND METHODS}

A split-split plot arrangement based on a randomized complete block design (RCBD) was conducted with three replications during two growing seasons (Spring-Summer 2017 and Spring-Summer 2018). Three irrigation methods, which included every furrow irrigation (EFI) $[\mathrm{I} 0]$ as a common practice in the region, fixed furrow irrigation (FFI) [I1] and alternate furrow irrigation (AFI) [I2] were allocated to the main plots, two cropping patterns were used, including one-row (sowing the sorghum seeds on one row) [P0] and two-rows (sowing the sorghum seeds on two rows) [P1] for the subplots, also, three levels of biochar application including 0 [B0], $6[\mathrm{~B} 1]$ and $12[\mathrm{~B} 2] \mathrm{t} \mathrm{ha}^{-1}$ to sub-sub plots. The experiments were carried out at the experimental research farm of Islamic Azad University - Karaj-Iran which is located at an altitude of $1313 \mathrm{~m}$ a.s.l. with the geographic coordinates of $50^{\circ} 54^{\prime}$ longitude and $35^{\circ} 28^{\prime}$ latitude. A normality test was performed for the collected data and then to ensure the uniformity of the treatment variations, a Bartlett's test was performed. In this experiment, the irrigation regime, cropping pattern and biochar treatments were considered to be a fixed factor and the year was assumed to be a random factor in the combined analysis of data An analysis of variance and the prepared figures were accomplished by using SAS Ver.9 and Microsoft Excel. Mean comparisons were performed using the Tukey HSD method test at a $5 \%$ probability level.

Each replicate consisted of 18 plots, each with 4 cultivated lines of $7 \mathrm{~m}$ in length and $5 \mathrm{~m}$ in width. The space between rows was arranged to be $0.6 \mathrm{~m}$ and the space between the plants was planned to be $0.1 \mathrm{~m}$ in each row. Plant density was devised to be 166,000 plant ha ${ }^{-1}$ of Sorghum (Sorghum bicolor L.). The seeds were sown on May 15, for each of the years that were investigated. Replanting was performed after seed emergence wherever required.

Biochar was mixed with the soil 14 days before the sowing date on May 15, 2017 and May 13, 2018. Follow up irrigations were performed from seed emergence until the growth stage of 4 leaves depending on the plant's requirements. Irrigation timing was determined using the method of Bafkar et al. (2017):

$$
I_{t}=\frac{d_{n}}{E T_{c}}
$$

where: $I_{t}$ is the irrigation cycle, $d_{n}$ is the net height of the irrigation water, and $E T_{c}$ is the rate of evapotranspiration of the plant.

Also, $d_{n}$ was calculated from the following equation (Bafkar et al., 2017):

$$
d_{n}=(F C-P W P)(M A D)(D),
$$

where: $D$ is the depth of root development in centimetres, $M A D$ - maximum allowable depletion, PWP - permanent wilting point, and $F C$ - field capacity.

The calculation of evapotranspiration $\left(E T_{c}\right)$ using the Blaney and Criddle (1964) method was performed using the following equation:

$$
E T_{c}=\alpha+\beta[P(0.46 T+8.13)],
$$

$\alpha$ and $\beta$ are the climatic variables, $T$ is the average monthly temperature $\left({ }^{\circ} \mathrm{C}\right)$, and $P$ is a fixed variable of the day. Some of the soil properties are listed in Table 1.

The applied biochar was based on forest wood and contained $84-88 \%$ carbon, $8-10 \%$ moisture, $5.8 \%$ of $\mathrm{pH}$, 950-1 $100 \mathrm{mg} \mathrm{g}^{-1}$ of iodine, $150-250 \mathrm{mg} \mathrm{g}^{-1}$ of methylene blue, and $4-8 \%$ of ash.

Five plants were randomly selected from each plot in order to measure the root traits. The roots were separated from the other vegetative parts of the plant, and then the washed roots were dried in an oven at $80^{\circ} \mathrm{C}$ for $48 \mathrm{~h}$. The root volume (RV) was measured by placing the roots in graduated cylinders and determining the rate of change in the water level.

The $\mathrm{CO}_{2}$ efflux emitted from the potting soil, is an indicator of the biological activity of the soil which was estimated according to the method described by Hopkins (2008). Plant sampling for the measurement of carbon mineralization was performed once during each growing season and after the final harvest (115 days after sowing date). 
Table 1. Soil characteristics at $0-30 \mathrm{~cm}$ depth range

\begin{tabular}{|c|c|c|c|c|c|c|c|c|c|c|c|}
\hline \multirow{2}{*}{ Soil parameter } & \multirow{2}{*}{$\begin{array}{c}\mathrm{EC} \\
\left(\mathrm{dS} \mathrm{m}^{-1}\right)\end{array}$} & \multirow{2}{*}{$\mathrm{pH}$} & Sand & Silt & Clay & \multirow{2}{*}{ Texture } & TNV & $\mathrm{OC}$ & Total N & \multirow{2}{*}{\multicolumn{2}{|c|}{$\left(\mathrm{mg} \mathrm{kg}^{-1}\right)$}} \\
\hline & & & & $(\%)$ & & & & $(\%)$ & & & \\
\hline 2017 & 5.81 & 7.76 & 49 & 31 & 20 & loam & 11.75 & 0.97 & 0.092 & 17.72 & 488.1 \\
\hline 2018 & 5.46 & 7.81 & 55 & 26 & 19 & $\begin{array}{l}\text { sandy- } \\
\text { loam }\end{array}$ & 12 & 0.91 & 0.080 & 22.02 & 818.4 \\
\hline
\end{tabular}

EC - electrical conductivity, TNV - total neutralizing value, OC - organic carbon.

A small plastic cup which contained 20 grams soil from each treatment, one vial containing $10 \mathrm{~mL}$ of $2 \mathrm{M} \mathrm{NaOH}$ and $10 \mathrm{~mL}$ of distilled water were added to the incubation jars with gastight lids (Mason Jar). The jars were then incubated in a dark room at $25^{\circ} \mathrm{C}$ for 10 days. The vials of $\mathrm{NaOH}$ were removed from the jars, $1 \mathrm{~mL}$ of $\mathrm{NaOH}\left(\mathrm{CO}_{2}\right.$ was trapped in the $\mathrm{NaOH}$ during the incubation period) and titrated with $0.02 \mathrm{~N} \mathrm{H}_{2} \mathrm{SO}_{4}$ using a burette with 3 drops of phenolphthalein as a $\mathrm{pH}$ indicator after the addition of $200 \mu \mathrm{L}$ of $1 \mathrm{M} \mathrm{BaCl}_{2}$ and $6.1 \mathrm{~mL}$ of $0.5 \mathrm{M}$ of $\mathrm{HCl}$. The results are expressed in $\mu \mathrm{mol} \mathrm{C} \mathrm{g}^{-1}$ soil $\mathrm{h}^{-1}$.

Plant shoots were harvested on two occasions. The first harvest (first cut) was performed when $10 \%$ of the plants in each plot entered into the flowering stage which was 70 days after the sowing date and the second harvest (second cut) was performed 45 days later. Plants of $2 \mathrm{~m}^{2}$ for each plot were harvested from $5 \mathrm{~cm}$ above the soil surface. The harvested shoots were then dried in an oven at $80^{\circ} \mathrm{C}$ for $48 \mathrm{~h}$.

\section{RESULTS AND DISCUSSION}

The results of the combined analysis showed that the effect of year, irrigation regime and biochar had a significant effect on root dry weight (RDW), root volume (RV), soil respiration (SR) and dry matter yield (DMY) (Table 2). The interaction effects of the irrigation regime, cropping pattern and biochar application on the RDW, RV and DMY at the first harvest were significant at a $1 \%$ probability level but had no significant effect on SR and DMY at the second harvest (Table 2). The mean comparison for the interaction effect of the irrigation regime $\times$ cropping pattern $\times$ biochar application on RDW showed that the highest RDW was observed for the I0P0B1, I0P1B2, I1P1B1, and I0P0B2 treatments $\left(31.55,30.74,27.60\right.$, and $27.30 \mathrm{~g} \mathrm{plant}^{-1}$, respectively), and the lowest value was related to the I2P1B0 treatment (14.86 $\mathrm{g} \mathrm{plant}^{-1}$ ) (Fig. 1). For the two-row cropping pattern, plant competition decreased and this pattern provided more suitable space for root growth to absorb moisture and nutrients. In this study, it was found that biochar improved soil hydraulic and moisture properties and caused increasing root moisture uptake under water deficit conditions. Improved root growth facilitated the uptake of water and nutrients which are required by the plant. Biochar may facilitate root growth and increase crop growth and yield by reducing the soil density and increasing water availability (Obia et al., 2016). Xiao et al. (2016) reported an increase in the root length of maize in the semi-arid region of Loess Plateau in China, due to biochar application. Biochar plays a role as a useful modifier to improve the physical and chemical properties of the soil, it is effective in maintaining soil organic matter, increasing fertilizer productivity and also increasing crop production, especially for long-term cultivated subtropical soils (Deenik et al., 2010; Van Zwieten et al., 2010). The mean comparison of the interaction effects of the irrigation regime $\times$ cropping pattern $\times$ biochar application on RV showed that the highest $\mathrm{RV}$ was observed in the I0P1B2, I1P0B2, I0P1B1, I0P0B1, I2P0B2, and I0P0B2 treatments $(60.39,60.00,55.81,54.42$, 54.17 , and $52.45 \mathrm{~cm}^{3}$ plant $^{-1}$, respectively), and the lowest was related to the IOP1B0 and I0P0B0 treatments (28.39 and $33.17 \mathrm{~cm}^{3}$ plant ${ }^{-1}$, respectively) (Fig. 2). The water deficit, especially during the vegetative growth period, reduced root development and RV. Increasing RV indicates further root development which allows for improved water and nutrient absorption capacity from a larger volume of soil. Thus, it appears that biochar application and changing the cropping pattern have partially reduced the adverse effects of drought stress, improved water uptake and nutrients and thus improved root growth and volume. Abiven et al. (2015) showed that the maize root biomass in the plots treated by biochar were almost doubled. Amendola et al. (2017) stated that with biochar application to the soil, the root diameter $(0.56 \mathrm{~mm})$ was increased compared to the control $(0.46 \mathrm{~mm})$, which led to an increase in root biomass. The analysis of variance showed that the effect of the irrigation regime on SR was significant at a 5\% probability level. A mean comparison showed that there were no significant differences between the irrigation treatments, although I1 was lower than I0 $\left(0.165\right.$ and $0.168 \mu \mathrm{mol} \mathrm{C} \mathrm{g}^{-1}$ soil $\mathrm{h}^{-1}$, respectively) (Fig. 3). Soil moisture is one of the most important factors affecting the soil microbial population and respiration, also, other studies have shown that water in the soil increases soil microbial respiration and there is a significant positive correlation between soil moisture and soil respiration (Jiang et al., 2013; Gong et al., 2015). The mean comparison of SR showed that there was a significant difference between the biochar application (B1 and B2) and the control (B0) treatments, and also, the highest SR was observed for the B2 and B1 treatments $(0.173$ and $0.171 \mu \mathrm{mol} \mathrm{C} \mathrm{g} \mathrm{g}^{-1}$ soil $\mathrm{h}^{-1}$, respectively), and conversely, 
Table 2. Analysis of variances of the effects of the experimental factors on root traits (DRW, RV), soil respiration (SR) and dry matter yield (DMY) of forage sorghum during 2017 and 2018

\begin{tabular}{|c|c|c|c|c|c|c|}
\hline \multirow{2}{*}{ S.O. V } & \multirow{2}{*}{$\mathrm{df}$} & \multirow{2}{*}{$\begin{array}{c}\text { DRW } \\
\left(\text { g plant }^{-1}\right)\end{array}$} & \multirow{2}{*}{$\begin{array}{c}\text { RV } \\
\left(\mathrm{cm}^{3} \text { plant }^{-1}\right)\end{array}$} & \multirow{2}{*}{$\begin{array}{c}\mathrm{SR} \\
\left(\mu \mathrm{mol} \mathrm{C} \mathrm{g^{-1 }} \text { soil h}^{-1}\right)\end{array}$} & \multicolumn{2}{|c|}{$\operatorname{DMY}\left(\mathrm{kg} \mathrm{ha}^{-1}\right)$} \\
\hline & & & & & First harvest & Second harvest \\
\hline Year & 1 & $4394^{* *}$ & $76284^{* *}$ & $32 \times 10^{-3} * *$ & $2.6 \times 10^{7 * *}$ & $1.14 \times 10^{8 *}$ \\
\hline R (Year) & 4 & 23.57 & 9.8 & $22 \times 10^{-6}$ & $8.37 \times 10^{5}$ & $3.69 \times 10^{6}$ \\
\hline Irrigation regiment (I) & 2 & $120^{*}$ & $277^{*}$ & $12 \times 10^{-5} *$ & $2.68 \times 10^{8 * *}$ & $1.83 \times 10^{8 * *}$ \\
\hline $\mathrm{I} \times$ Year & 2 & $90.68^{*}$ & $260^{*}$ & $40 \times 10^{-6}$ ns & $2.19 \times 10^{6 \mathrm{~ns}}$ & $3.92 \times 10^{7 * *}$ \\
\hline Error main plots & 8 & 10.27 & 24.3 & $11 \times 10^{-6}$ & $5.58 \times 10^{6}$ & $2.37 \times 10^{6}$ \\
\hline Cropping pattern $(\mathrm{P})$ & 1 & $191^{*}$ & $5.2^{\mathrm{ns}}$ & $18 \times 10^{-6 \mathrm{~ns}}$ & $2.64 \times 10^{7 * *}$ & $1.58 \times 10^{7 *}$ \\
\hline $\mathrm{P} \times$ Year & 1 & $25.1^{\mathrm{ns}}$ & $227^{*}$ & $33 \times 10^{-7 \mathrm{~ns}}$ & $4.26 \times 10^{7 *}$ & $3.13 \times 10^{6 \mathrm{~ns}}$ \\
\hline $\mathrm{P} \times \mathrm{I}$ & 2 & $38.1^{\mathrm{ns}}$ & $82.1^{\mathrm{ns}}$ & $60 \times 10^{-6 \mathrm{~ns}}$ & $1.48 \times 10^{7 \mathrm{~ns}}$ & $1.61 \times 10^{7 \mathrm{~ns}}$ \\
\hline $\mathrm{P} \times \mathrm{I} \times$ Year & 1 & $28.8^{\mathrm{ns}}$ & $6.2^{\mathrm{ns}}$ & $84 \times 10^{-6 \mathrm{~ns}}$ & $2.38 \times 10^{6 \mathrm{~ns}}$ & $8.75 \times 10^{5 \mathrm{~ns}}$ \\
\hline Error sub plots & 12 & 11.44 & 22.3 & $14 \times 10^{-6}$ & $3.10 \times 10^{6}$ & $1.17 \times 106$ \\
\hline Biochar (B) & 2 & $244^{* *}$ & $2141^{* *}$ & $20 \times 10^{-5 * *}$ & $1.61 \times 10^{6} \mathrm{~ns}$ & $3.09 \times 10^{6 *}$ \\
\hline $\mathrm{B} \times$ Year & 2 & $200^{* *}$ & $477^{* *}$ & $99 \times 10^{-6 *}$ & $2.74 \times 10^{6} \mathrm{~ns}$ & $1.33 \times 10^{7 * *}$ \\
\hline $\mathrm{B} \times \mathrm{I}$ & 4 & $9.08^{\mathrm{ns}}$ & $481^{* *}$ & $33 \times 10^{-6 \mathrm{~ns}}$ & $1.11 \times 10^{7 * *}$ & $3.53 \times 10^{6 * *}$ \\
\hline $\mathrm{B} \times \mathrm{I} \times$ Year & 4 & $4.54^{\mathrm{ns}}$ & $976^{* *}$ & $95 \times 10^{-7 \mathrm{~ns}}$ & $1.56 \times 10^{7 * *}$ & $2.15 \times 10^{6 * *}$ \\
\hline $\mathrm{B} \times \mathrm{P}$ & 2 & $79.8^{* *}$ & $223^{*}$ & $45 \times 10^{-6 \mathrm{~ns}}$ & $3.14 \times 10^{6} \mathrm{~ns}$ & $6.45 \times 10^{5 \mathrm{~ns}}$ \\
\hline $\mathrm{B} \times \mathrm{P} \times$ Year & 2 & $36.1^{*}$ & $226^{*}$ & $50 \times 10^{-6}$ ns & $2.55 \times 10^{7 * *}$ & $7.23 \times 10^{6 * *}$ \\
\hline $\mathrm{B} \times \mathrm{P} \times \mathrm{I}$ & 4 & $94.4^{* *}$ & $307^{* *}$ & $24 \times 10^{-6 \mathrm{~ns}}$ & $6.90 \times 10^{6} *$ & $4.01 \times 10^{5 \mathrm{~ns}}$ \\
\hline $\mathrm{B} \times \mathrm{P} \times \mathrm{I} \times$ Year & 4 & $72.7^{* *}$ & $329^{* *}$ & $32 \times 10^{-6 \mathrm{~ns}}$ & $5.90 \times 10^{6} *$ & $9.50 \times 10^{5 \mathrm{~ns}}$ \\
\hline Error & 48 & 4.89 & 34.6 & $13 \times 10^{-6}$ & $1.22 \times 10^{6}$ & $4.10 \times 10^{5}$ \\
\hline $\mathrm{CV}(\%)$ & - & 8.96 & 12.51 & 2.08 & 9.01 & 12.17 \\
\hline
\end{tabular}

Significant at: $* \mathrm{p} \leq 0.05, * * \mathrm{p} \leq 0.01, \mathrm{~ns}-$ non-significant.

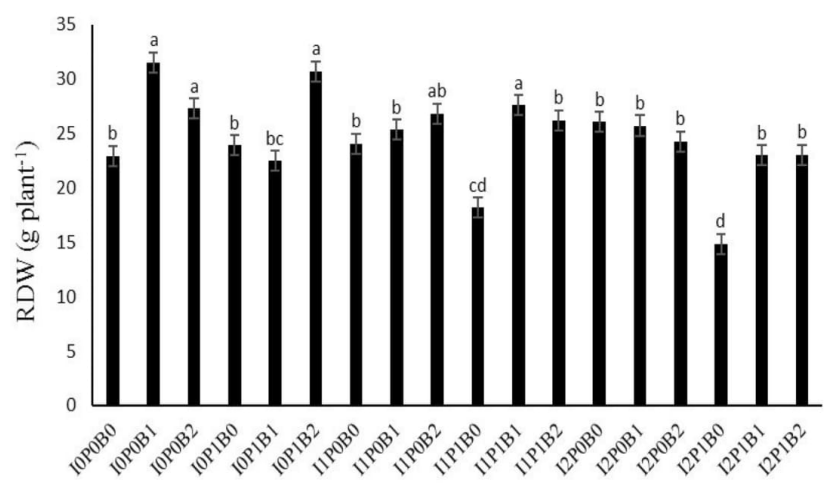

Fig. 1. Mean comparison of root dry weight (RDW) in cropping seasons of 2017 and 2018. I0 - every furrow irrigation (EFI), I1 - fixed furrow irrigation (FFI), I2 - alternate furrow irrigation (AFI), P0 - one-row cropping pattern, $\mathrm{P} 1$ - two-rows cropping pattern; $\mathrm{B} 0-0, \mathrm{~B} 1-6, \mathrm{~B} 2-12 \mathrm{t} \mathrm{ha}^{-1}$ of biochar. Columns with at least one common alphabet, according to the Tukey's HSD test, have no significant difference at the $5 \%$ level. the lowest value was observed in the control treatment $\left(0.168 \mu \mathrm{mol} \mathrm{C} \mathrm{g}{ }^{-1}\right.$ soil h$\left.^{-1}\right)$ (Fig. 4). Microbial respiration is closely related to soil organic carbon. Increasing the levels of carbon in the soil provides nutrients for microorganisms, which increases their metabolism activity and also results in increased $\mathrm{CO}_{2}$ emissions. The application of biochar in the soil increased the level of organic carbon, reduced soil density and increased maize yield which means that biochar, as a soil modifier, simultaneously increased the yield and reduced greenhouse gas emissions (Zhang et al., 2012). The results of the study by Sagrilo et al. (2014) showed that with the use of biochar, the amount of carbon released into the soil was increased. In another experiment conducted by Liu et al. (2016), the results showed that the use of biochar did not affect soil respiration. It seems that biochar reduces greenhouse gas emissions, but due to the source of biomass and the biochar production process, it may have a different effect. As the results shown in Fig. 4 demonstrate, biochar had a positive effect on reducing $\mathrm{CO}_{2}$ emissions. A mean comparison of the interaction effects of the irrigation regime $\times$ cropping pattern $\times$ biochar application 


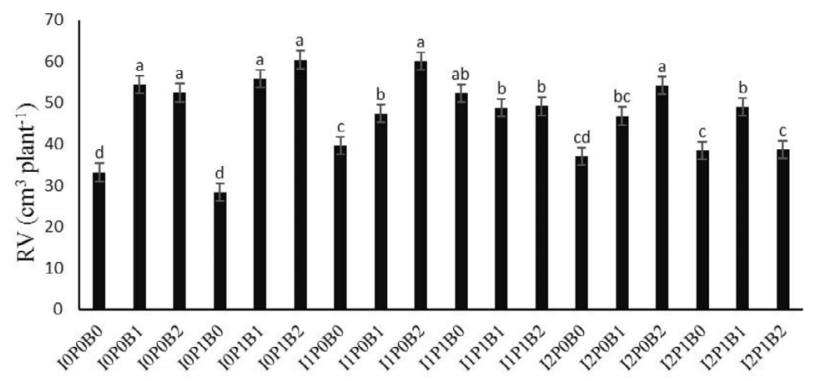

Fig. 2. Mean comparison of root volume (RV) in cropping seasons of 2017 and 2018. Explanation as in Fig. 1.

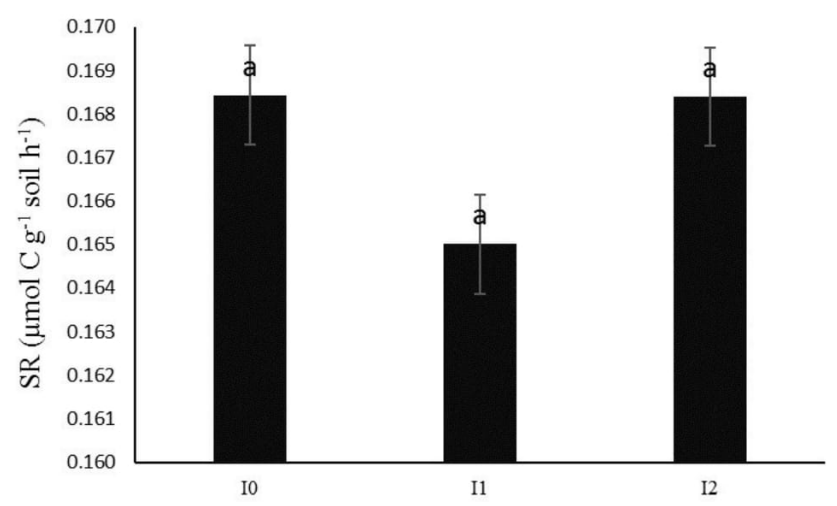

Fig. 3. Mean comparison of soil respiration (SR) [C mineralization rate] in cropping seasons of 2017 and 2018. I0 - every furrow irrigation (EFI), I1 - fixed furrow irrigation (FFI), I2 - alternate furrow irrigation (AFI). Other explanations as in Fig. 1.

on DMY at the first harvest showed that the highest DMY were related to I0P1B0, I0P0B0, I0P1B2, and I0P0B2 treatments $\left(16550,15447,15148\right.$, and $14842 \mathrm{~kg} \mathrm{ha}^{-1}$, respectively) and that the I0P1B1, I0P0B1, I1P0B2, I1P0B0 treatments had a lower intensity of dry forage yield loss $\left(13432,13395,13098\right.$, and $12728 \mathrm{~kg} \mathrm{ha}^{-1}$, respectively) (Fig. 5). Biochar application reduces soil compaction and improves water retention at the wilting point and also increases water availability (Buss et al., 2012; Abel et al., 2013). The main reason for the decreased DMY in crops under low irrigation conditions is the decrease in leaf area, which reduces the efficiency of the light received. Drought stress in wheat reduced chlorophyll content, leaf photosynthesis, spike fertility, seed number, and grain yield (Prasad et al., 2011). The mean comparison of the irrigation regime for the second harvest showed that the highest DMY was related to $\mathrm{I} 0$ while the lowest were related to the $\mathrm{I} 2$ and I1 treatments (4765 and $3428 \mathrm{~kg} \mathrm{ha}^{-1}$, respectively) (Fig. 6). Low-irrigation appears to have a significantly adverse effect on sorghum DMY. Under soil water shortage conditions, the leaf water content is reduced, stomata are closed and gas exchange is limited, which reduces photosynthesis and yield (Mutava et al., 2011). The mean comparisons showed

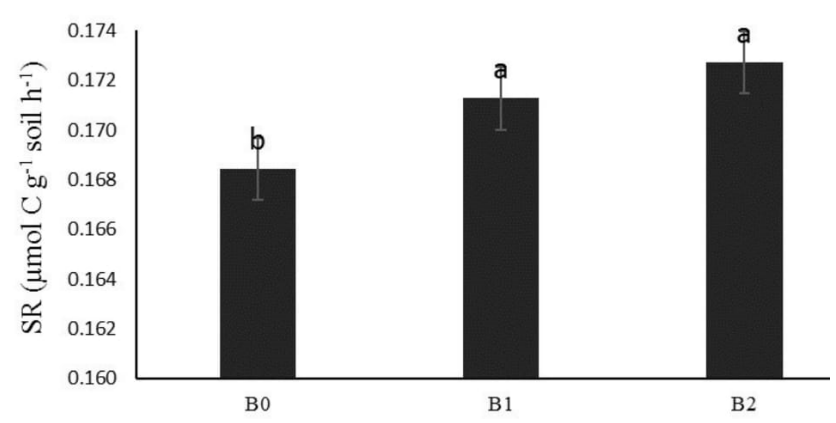

Fig. 4. Mean comparison of soil respiration (SR) [C mineralization rate] in cropping seasons of 2017 and 2018. B0 - 0, B1 - 6, $\mathrm{B} 2-12 \mathrm{t} \mathrm{ha}^{-1}$ of biochar. Other explanations as in Fig. 1.

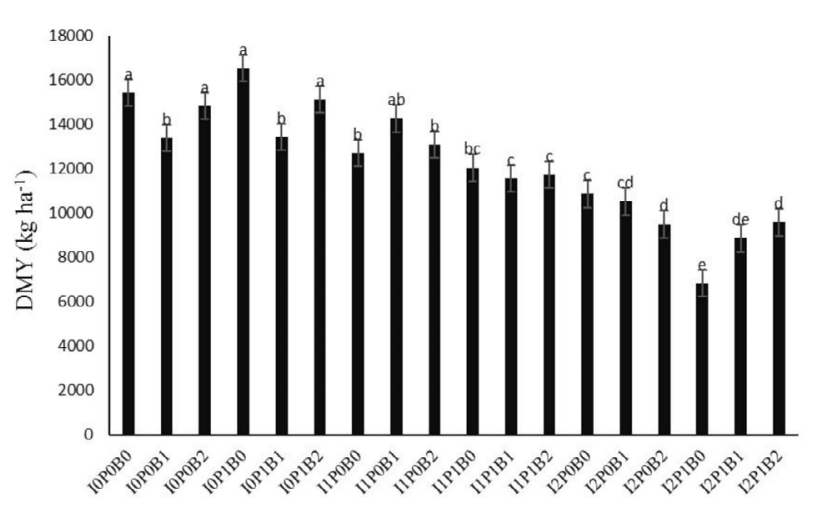

Fig. 5. Mean comparison of dry matter yield (DWY) in cropping seasons of 2017 and 2018. I0 - every furrow irrigation (EFI), I1 - fixed furrow irrigation (FFI), I2 - alternate furrow irrigation (AFI), P0 - one-row cropping pattern, $\mathrm{P} 1$ - two-rows cropping pattern; $\mathrm{B} 0-0, \mathrm{~B} 1-6, \mathrm{~B} 2-12 \mathrm{t} \mathrm{ha}^{-1}$ of biochar. Other explanations as in Fig. 1.

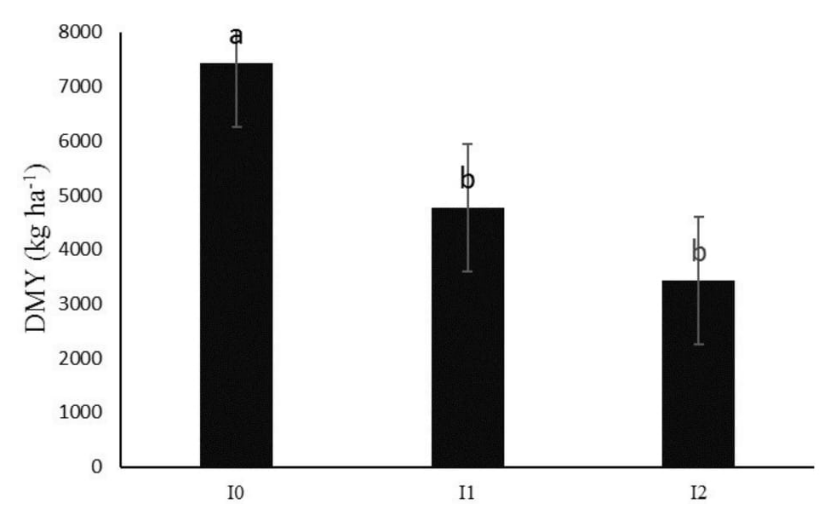

Fig. 6. Mean comparison of dry matter yield (DWY) in cropping seasons of 2017 and 2018. I0 - every furrow irrigation (EFI), I1 - fixed furrow irrigation (FFI), I2 - alternate furrow irrigation (AFI). Other explanations as in Fig. 1.

that biochar application significantly improved the DMY and that the highest DMY was observed in the B2 treatment (7983 $\mathrm{kg} \mathrm{ha}^{-1}$ ) (Fig. 7). It seems that biochar increased DMY by providing water and nutrients to the crop. In 


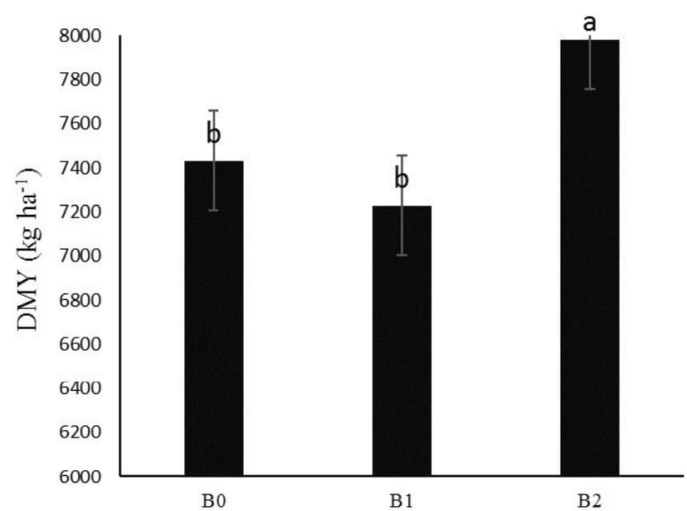

Fig. 7. Mean comparison of dry matter yield (DWY) in cropping seasons of 2017 and 2018. B0 - 0, B1 - 6, B2 - $12 \mathrm{t} \mathrm{ha}^{-1}$ of biochar. Other explanations as in Fig. 1.

most cases, biochar application improved the properties of the soil, although in some cases, its adverse effects were observed, which may be due to the insufficient application of biochar. The beneficial effects of biochar increase the availability of water (Cornelissen et al., 2013; Moosavi et al., 2020), thereby increasing soil moisture retention (Buss et al., 2012) and improving soil chemical properties such as increasing the level of soil organic carbon, soil nitrogen and nutrient uptake (Ma et al., 2016). There was no correlation between the root characteristics, SR and DMY (Table 3).

\section{CONCLUSIONS}

1.The results showed that the addition of biochar to the soil under furrow irrigation conditions and a two-row cropping pattern had a significant effect on the morphological traits of sorghum roots and increased root dry weight and root volume, but the dry matter yield declined slightly.

2. Among the interaction effects of the irrigation methods, the cropping pattern and biochar, the fixed furrow irrigation treatment with a constant two-row cropping pattern and biochar application compared to the control treatment had a better effect on these properties and reduced the limiting effects of low irrigation. Therefore, it may be stated that under fixed furrow irrigation conditions, constant stress and optimum moisture conditions existed on one side of the furrow, and the plant was able to adapt its root system better to the prevailing conditions.

3. Regarding the amount of biochar application, under the fixed furrow irrigation method and the two-row cropping pattern, biochar application could improve the root dry weight and root volume. Additionally, the application of biochar compared to non-biochar, increased soil respiration and carbon storage, while also enhancing soil quality and improving dry matter yield.

4. The results of this study showed that biochar, due to its high concentration of pores and high-water holding capacity, improved root growth under water stress conditions, and to some extent, prevented a decrease in dry matter yield.

Conflict of interest: The authors declare no conflict of interest.

\section{REFERENCES}

Afshari M., Naderi A., Mojadam M., Lack S., and Alavifazel M., 2020. Zinc and iron-mediated alleviation water deficiency of maize by modulating antioxidant metabolism. Not. Bot. Hort. Agrobot., 48, 989-1004. https://doi. org/10.15835/nbha48211923

Abel S., Peters A., Trinks S., Schonsky H., Facklam M., and Wessolek G., 2013. Impact of biochar and hydrochar addition on water retention and water repellency of sandy soil. Geoderma, 203, 183-191.

https://doi.org/10.1016/j.geoderma.2013.03.003

Abiven S., Hund A., Martinsen V., and Cornelissen G., 2015. Biochar amendment increases maize root surface areas and branching: a shovelomics study in Zambia. Plant Soil, 395, 45-55. https://doi.org/10.1007/s11104-015-2533-2

Akpa S.I.C., Odeh I.O.A., and Bishop T.F.A., 2014. Digital mapping of soil particle - size fractions for Nigeria. Soil Sci. Soc. Am. J., 78, 1953-1966. https://doi.org/10.2136/ sssaj2014.05.0202

Table 3. Results of correlation constants between different cropping patterns of forage sorghum during 2017 and 2018

\begin{tabular}{|c|c|c|c|c|}
\hline & $\begin{array}{c}\text { RDW } \\
\left(\text { g plant }^{-1}\right)\end{array}$ & $\begin{array}{c}\mathrm{RV} \\
\left(\mathrm{cm}^{3} \text { plant }^{-1}\right) \\
\end{array}$ & $\begin{array}{c}\mathrm{SR} \\
\left(\mu \mathrm{mol} \mathrm{C \textrm {g } ^ { - 1 }} \text { soil h} \mathrm{h}^{-1}\right)\end{array}$ & $\begin{array}{c}\text { DWY [harvest 1] } \\
\left(\mathrm{kg} \mathrm{ha}^{-1}\right)\end{array}$ \\
\hline $\mathrm{RV}\left(\mathrm{cm}^{3}\right.$ plant $\left.^{-1}\right)$ & $0.404^{\text {ns }}$ & 1 & & \\
\hline $\operatorname{SR}\left(\mu \mathrm{mol} \mathrm{C} \mathrm{g}^{-1}\right.$ soil h$\left.^{-1}\right)$ & $0.200^{\mathrm{ns}}$ & $0.178^{\text {ns }}$ & 1 & \\
\hline DWY [harvest 1] $\left(\mathrm{kg} \mathrm{ha}^{-1}\right)$ & $0.482^{\text {ns }}$ & $0.19^{\mathrm{ns}}$ & $-0.226^{\mathrm{ns}}$ & 1 \\
\hline DWY [harvest 2] $\left(\mathrm{kg} \mathrm{ha}^{-1}\right)$ & $0.462^{\mathrm{ns}}$ & $0.092^{\mathrm{ns}}$ & $0.117^{\mathrm{ns}}$ & $0.805^{* *}$ \\
\hline
\end{tabular}

Significant at: ${ }^{*} \mathrm{p} \leq 0.05,{ }^{* *} \mathrm{p} \leq 0.01$. RDW - root dry weight, RV - root volume, $\mathrm{SR}$ - soil respiration, DWY - dry weight yield; ns - non-significant. 
Amendola C., Montagnoli A., Terzaghi M., Trupiano D., Oliva F., Baronti S., Miglietta F., Chiatante D., and Scippa G.S., 2017. Short-term effects of biochar on grapevine fine root dynamics and arbuscular mycorrhizae production. Agric. Ecosyst. Environ., 239, 236-245. https://doi. org/10.1016/j.agee.2017.01.025

Ardakani M.R., Pietsch G., Moghaddam A., Raza A., and Friedel J.K., 2009. Response of root properties to tripartite symbiosis between lucerne (Medicago sativa L.), rhizobia and mycorrhiza under dry organic farming conditions. Am. J. Agric. Biol. Sci., 4, 266-277. https:// doi: 10.3844/ ajabssp.2009.266.277

Bafkar A., Ghamarniya H., and Taheri Tizro A., 2017. Principles of general Irrigation. Kermanshah, Iran. 23-27. ISBN: 978-600-393-018-6.

Blaney H.F. and Criddle W.D., 1964. Determining water requirements for settling water disputes. Natural. Res J., 4(1), 29-41.

Borrell A.K., Mullet J.E., George-Jaeggli B., van Oosterom E.J., Hammer G.L., Klein E., and Jordan D.R., 2014. Drought adaptation of stay-green sorghum is associated with canopy development, leaf anatomy, root growth, and water uptake. J. Exp. Bot., 63, 6251-6263. doi:10.1093/jxb/ eru232.

Brennan A., Jiménez E.M., Puschenreiter M., Alburquerque J.A., and Switzer C., 2014. Effects of biochar amendment on root traits and contaminant availability of maize plants in a copper and arsenic impacted soil. Plant Soil, 379, 351360. doi: 10.1007/s11104-014-2074-0

Buss W., Kammann C., and Koyro H.W., 2012. Biochar reduces copper toxicity in Chenopodium quinoa wild in a sandy soil. J. Environ Quality, 40, 1157-1165. https://doi. org/10.2134/jeq2011.0022

Chai Q., Gan Y., Turner N.C., Zhang R.Z., Yang C., Niu Y., and Siddique K.H.M., 2014. Water-saving innovations in Chinese agriculture. Adv. Agron., 126,147-197. doi:10.1016/B978-0-12-800132-5.00002-X.

Chimungu J.G., Brown K.M., and Lynch J.P., 2014. Large root cortical cell size improves drought tolerance in maize (Zea mays L.). Plant Physiol., 166, 1943-1955. https://doi. org/10.1104/pp.114.250449

Cornelissen G., Martinsen V., Shitumbanuma V., Alling V., Breedveld G., Rutherford D., Sparrevik M., Hale S., Obia A., and Mulder J., 2013. Biochar effect on maize yield and soil characteristics in five conservation-farming sites in Zambia. Agronomy, 3, 256-274. https://doi.org/10.3390/agronomy3020256

Cox W.J., Hanchar J.J., Knoblauch W.A., and Cherney J.H., 2006. Growth, yield, quality and economics of cron silage under different row spacings. J. Agron., 98, 163-167. https:// doi.org/10.2134/agronj2005.0133

Deenik J.L., McClellan T., Uehara G., Antal M.J., and Campbell S., 2010. Charcoal volatile matter content influences plant growth and soil nitrogen transformation. Soil Sci. Soc. Am. J., 74, 1259-70. https://doi.org/10.2136/ sssaj2009.0115

Forouzani M. and Karami E., 2011. Agricultural water poverty index and sustainability. Agron. Sustain. Dev., 31, 415-432. doi:10.1051/agro/2010026.
Gong J.R., Xu S., Wang Y., Luo Q., Liu M., and Zhang W., 2015. Effect of irrigation on the soil respiration of constructed grasslands in Inner Mongolia, China. Plant Soil, 395, 159-172. doi 10.1007/s11104-015-2534-1

He X., Du Z., Wang Y., Lu N., and Zhang Q., 2016. Sensitivity of soil respiration to soil temperature decreased under deep biochar amended soils in temperate croplands. Appl. Soil Ecol., 108, 204-210. https://doi.org/10.1016/j.apsoil.2016.08.018

Hopkins D.W., 2008. Carbon mineralization. In: Soil sampling and methods of analysis (Eds M.R. Carter, E.G. Gregorich). CRC Press, USA.

Hoseinzade H., Ardakani M.R., Shahdi A., Asadi Rahmani H., Noormohammadi G., and Miransari M., 2016. Rice (Oryza sativa L.) nutrient management using mycorrhizal fungi and endophytic Herbaspirillum seropedicae. J. Integr. Agri., 15, 1385-1394. doi.org/10.1016/S2095-3119(15)61241-2

Jeffery S., Meinders M.B.J., Stoof C.R., Bezemer T., van de Voorde T.F.J., Mommer L., and van Groenigen J.W., 2015. Biochar application does not improve the soil hydrological function of a sandy soil. Geoderma, 252, 47-54. https://doi.org/10.1016/j.geoderma.2015.03.022

Jiang H., Deng Q., Zhou G., Hui D., Zhang D., Liu S., and Chu G., 2013. Responses of soil respiration and its temperature/ moisture sensitivity to precipitation in three subtropical forests in southern China. Biogeosciences, 10, 3963-3982. doi:10.5194/bg-10-3963-2013

Kang S.Z. and Zhang J.H., 2004. Controlled alternate partial rootzone irrigation: Its physiological consequences and impact on water use efficiency. J. Exp. Bot., 55, 2437-2446. https://doi.org/10.1093/jxb/erh249

Kurt C., Bakal H., Gulloglu L., and Arioglu H., 2017. The effect of twin row planting pattern and plant population on yield and yield components of peanut (Arachis hypogaea L.) at main crop planting in cukurova region of Turkey. Turk. J. Field Crops, 22, 24-31. https://doi.org/10.17557/ tjfc.301768

Liu H., Wang X., Wang D., Zou Z., and Liang Z., 2011. Effect of drought stress on growth and accumulation of active constituents in Salvia miltiorrhiza Bunge. Ind. Crops Prod., 33, 84-88. https://doi.org/10.1016/j.indcrop.2010.09.006

Liu P., Yin L.N., Deng X.P., Wang S.W., Tanaka K., and Zhang S.Q., 2014. Aquaporin-mediated increase in root hydraulic conductance is involved in silicon-induced improved root water uptake under osmotic stress in Sorghum bicolor L. J. Exp. Bot., 65, 4747-4756. doi: 10.1093/jxb/eru220

Liu X., Zheng J., Zhang D., Cheng K., Zhou H., Zhang A., Li L., Joseph S., Smith P., Crowley D., Kuzyakov Y., and Pan G., 2016. Biochar has no effect on soil respiration across Chinese agricultural soils. Sci. Total Environ., 554555, 259-265. https://doi.org/10.1016/j.scitotenv.2016.02.179

Ma N., Zhang L., Zhang Y., Yang L., Yu C., Tin G., Diane T.A., and Ma X., 2016. Biochar improves soil aggregate stability and water availability in a mollisol after three years of field application. PLOS One, 11(5), 1-10. 
Masto R.E., Kumar S., Rout T.K., Sarkar P., George J., and Ram L.C., 2013. Biochar from water hyacinth (Eichornia crassipes) and its impact on soil biological activity. Catena, 111, 64-7. https://doi.org/10.1016/j.catena.2013.06.025

Moosavi S.A., Shokuhfar A., Lak S., Mojaddam M., and Alavifazel M., 2020. Integrated application of biochar and bio-fertilizer improves yield and yield components of cowpea under water-deficient stress. Ital. J. Agron., 15, 94-101. https://doi.org/10.4081/ija.2020.1581

Moslemi Z., Habibi D., Asgharzadeh A., Ardakani M.R., Mohammadi A., and Sakari A., 2011. Effects of super absorbent polymer and plant growth promoting rhizobacteria on yield and yield components of maize under drought stress and normal conditions. Afr. J. Agric. Res., 6, 44714476. https:// doi: 10.5897/AJAR10.462

Mutava R.N, Prasad P.V.V., Tuinstra M.R., Kofoid K.D., and Yu J., 2011. Characterization of sorghum genotypes for traits related to drought tolerance. Field Crop Res., 123,1018. https://doi.org/10.1016/j.fcr.2011.04.006

Obia A., Mulder J., Martinsen V., Cornelissen G., and Børresen T., 2016. In situ effects of biochar on aggregation, water retention and porosity in light-textured tropical soils. Soil Till. Res., 155, 35-44. https://doi.org/10.1016/j. still.2015.08.002

Prasad P.V.V., Pisipati S.R., Momcilovic I., and Ristic Z., 2011. Independent and combined effects of high temperature and drought stress during grain filling on plant yield and chloroplast EF-Tu expression in spring wheat. J. Agron. Crop Sci., 931-2250.

https://doi.org/10.1111/j.1439-037X.2011.00477.x

Randhawa M.S., Maqsood M., Shehzad M.A., Chatta M.U., Chatta M.B., Nawaz F., Yasin S., Abbas T., Nawaz M.M., Khan R.D., and Zulfiqar U., 2017. Light interception, radiation use efficiency and biomass accumulation response of maize to integrated nutrient management under drought stress conditions. Turk. J. Field Crops, 221, 134-142. https://doi.org/10.17557/tjfc. 312370

Sagrilo E., Jeffery S., Hoffland E., and Kuyper T.W., 2014. Emission of $\mathrm{CO}_{2}$ from biochar amended soils and implications for soil organic carbon. GCB Bioenergy, 7, 1294-1304. https://doi.org/10.1111/gcbb.12234
Samarbakhsh S., Rejali F., Ardakani M.R., Nejad F.P., and Miransari M., 2009. The combined effects of fungicides and arbuscular Mycorrhiza on corn (Zea mays L.) growth and yield under field conditions. J. Biol. Sci., 9, 372-376. doi: $10.3923 /$ jbs.2009.372.376

Sun C.X., Chen X., Cao M.M., Li M.Q., and Zhang Y.L., 2017. Growth and metabolic responses of maize roots to straw biochar application at different rates. Plant Soil, doi: 10.1007/s11104-017-3229-6.

Sutka M., Li G., Boudet J., Boursiac Y., Doumas P., and Maurel C., 2011. Natural variation of root hydraulics in arabidopsis grown in normal and salt-stressed conditions. Plant Physiol, 155, 1264-1276. doi: https://doi.org/10.1104/ pp. 110.163113

Van Zwieten L., Kimber S., Morris S., Chan K.Y., Downie A., Rust J., Joseph S., and Cowie A., 2010. Effects of biochar from slow pyrolysis of papermill waste on agronomic performance and soil fertility. Plant Soil, 327, 235-246. doi. 10.1007/s11104-009-0050-x

Wu Y., Du T., Li F., Li S., Ding R., and Tong L., 2015. Quantification of maize water uptake from different layers and root zones under alternate furrow irrigation using stable oxygen isotope. Agric. Water Manag., 168, 35-44. https:// doi.org/10.1016/j.agwat.2016.01.013

Xiao Q., Zhu L.X., Zhang H.P., Li X.Y., Shen Y.F., and Li S.Q., 2016. Soil amendment with biochar increases maize yields in a semi-arid region by improving soil quality and root growth. Crop Pasture Sci., 67, 495-507. http://dx.doi. org/10.1071/CP15351

Xiao Y., Zhang J., Jia T.T., Pang X., and Guo Z.G., 2015. Effects of alternate furrow irrigation on the biomass and quality of alfalfa (Medicago sativa). Agric. Water Manag., 161, 147-154. https://doi.org/10.1016/j.agwat.2015.07.018

Zhang A., Liu Y., Pan G., Hussain Q., Li L., Zheng J., and Zhang X., 2012. Effect of biochar amendment on maize yield and greenhouse gas emissions from a soil organic carbon poor calcareous loamy soil from from central China plain. Plant Soil, 351, 263-275. doi. 10.1007/s11104-011-0957-x 